University of Nebraska - Lincoln

DigitalCommons@University of Nebraska - Lincoln

Faculty Publications: Department of Entomology

1996

\title{
Population Genetics and Gene Variation of Stable Fly Populations (Diptera: Muscidae) in Nebraska
}

\author{
Allen L. Szalanski \\ University of Nebraska-Lincoln \\ David B. Taylor \\ University of Nebraska-Lincoln, dave.taylor@ars.usda.gov \\ Richard D. Peterson II \\ University of Nebraska-Lincoln, padr20@yahoo.com
}

Follow this and additional works at: https://digitalcommons.unl.edu/entomologyfacpub

Part of the Entomology Commons

Szalanski, Allen L.; Taylor, David B.; and Peterson, Richard D. II, "Population Genetics and Gene Variation of Stable Fly Populations (Diptera: Muscidae) in Nebraska" (1996). Faculty Publications: Department of Entomology. 198.

https://digitalcommons.unl.edu/entomologyfacpub/198

This Article is brought to you for free and open access by the Entomology, Department of at DigitalCommons@University of Nebraska - Lincoln. It has been accepted for inclusion in Faculty Publications: Department of Entomology by an authorized administrator of DigitalCommons@University of Nebraska - Lincoln. 


\title{
Population Genetics and Gene Variation of Stable Fly Populations (Diptera: Muscidae) in Nebraska
}

\author{
ALLEN L. SZALANSKI,' DAVID B. TAYLOR, AND RICHARD D. PETERSON II \\ Midwest Livestock Insects Research Laboratory, USDA-ARS, Department of Entomology, \\ University of Nebraska, Lincoln, NE 68583
}

\begin{abstract}
J . Med. Entomol. 33(3): 413-420 (1996)
ABSTRACT Genetic variation in stable fly, Stomoxys calcitrans (L.), populations from Nebraska, Canada, and Texas was sampled. Four of 12 allozyme loci were polymorphic, with an average of 1.7 alleles per locus. Observed and expected heterozygosities were 0.086 and 0.070 , respectively. Nei's genetic distance between populations averaged 0.001 and ranged from 0.000 to 0.005 . Wright's F statistics revealed greater variation within than among populations. Allele frequencies were homogeneous among temporal samples from a single population. Polymerase chain reaction-restriction fragment length polymorphism (PCR-RFLP) analysis of $6.4 \mathrm{~kb}$ of the mitochondrial DNA genome with 16 restriction enzymes revealed no variation in stable fly populations from Canada, Nebraska, and Texas. PCR-RFLP analysis of a $2.0-\mathrm{kb}$ fragment of the nuclear ribosomal DNA internally transcribed spacer region also revealed no variation. The lack of genetic differentiation among stable fly populations indicates high levels of gene How among populations. The low levels of variation observed with biochemical and molecular techniques are consistent with a genetic bottleneck during stable fly colonization of North America.
\end{abstract}

KEY WORDS Stomoxys calcitrans, population genetics, isozymes, polymerase chain reaction-restriction fragment length polymorphism

THE STABLE FLY, Stomoxys calcitrans (L.), is a widespread, economically important pest of man and animals (Campbell and Hermanussen 1971, Christensen 1982). This species is cosmopolitan, but most abundant in temperate zones (

1985), where dense populations are associated with confined livestock (Hoffman 1968). Stable fly biting activity reduces weight gain and feed efficiency in cattle (Estienne et al. 1991, Weiman et al. 1992). In addition, stable fly is an important pest of humans at the expanding rural-urban interface (Thomas 1993). Stable fly control technologies, including sanitation and insecticides, are generally unsatisfactory (Hoffman 1968) and knowledge of components of stable fly biology needed for the development of new control strategies is inadequate. Information on overwintering populations (Berry et al. 1978, Berkebile et al. 1994) and stable fly dispersal (Jones et al. 1987) is insufficient for modeling population dynamics and evaluating control strategies for this insect.

Previous studies (Jones et al. 1991, Krafsur 1993) on stable fly population genetics have measured allozyme variation in geographically dispersed populations. The purpose of our study was to examine genetic variation of stable fly in local

\footnotetext{
'Current address: Department of Plant Pathology, 406 Plant Science Building, University of Nebraska at Lincoln, Lincoln, NE 68583-0722.
}

and dispersed geographic populations using allozymes and to correlate allozyme variation with DNA markers. A nested sampling structure was used to compare variation within and among geographically adjacent and distant populations. This was the 1 st effort to compare allozyme, mtDNA, and nuclear rDNA variation of a muscid species within and among the same populations.

\section{Methods and Materials}

Stable Flies. Stable flies were collected from stanchioned calves (Thomas et al. 1989) or by sweep-netting from vegetation and sunny surfaces. Flies were collected from 4 feedlots within $40 \mathrm{~km}$ of Lincoln, NE; 3 feedlots within $35 \mathrm{~km}$ of Grand Island, NE (130 km west of Lincoln); 1 feedlot at Elgin, NE (150 km north of Lincoln); and from Buffalo Point, MB, Canada $(1,500 \mathrm{~km}$ north of Lincoln) (Table 1). One of the Lincoln area feedlots (Panama, NE) was sampled 3 times in 1992 and once in 1993 to examine temporal variation. Flies were also examined from the Kerrville laboratory colony (maintained at the USDA-ARS Livestock Insects Research Laboratory, University of Nebraska at Lincoln and derived from a colony at the Agricultural Research Service, USDA Livestock Insects Laboratory Kerrville, TX, which was collected from near Kerrville, TX in 1952 and nev- 
Table 1. Sampling locations and dates for collections of stable fly

\begin{tabular}{|c|c|c|c|}
\hline Sampling location & Abbreviation & Locality, state & Collection date \\
\hline Seward, Seward County & SEW & Lincoln, NE & 26 July 1992 \\
\hline Hickman, Lancaster County & HIC & Lincoln, NE & 21 June 1992 \\
\hline Valparaiso, Saunders County & VAL & Lincoln, NE & 12 July 1992 \\
\hline Panama, Lancaster County & & Lincoln, NE & 28 June 1992 \\
\hline Panama, Lancaster County & PA2 & Lincoln, NE & 12 July 1992 \\
\hline Panama, Lancaster County & PA3 & Lincoln, NE & 9 Aug. 1992 \\
\hline Panama, Lancaster County & PA4 & Lincoln, NE & 19 Aug. 1992 \\
\hline Grand Island, Hall County & GRI & Grand Island, NE & 9 Aug. 1992 \\
\hline St. Paul, Howard County & STP & Grand Island, NE & 20 Aug. 1993 \\
\hline Dannebrog, Howard County & DAN & Grand Island, NE & 20 Aug. 1993 \\
\hline Elgin, Antelope County & ELG & Norfolk, NE & 15 Aug. 1993 \\
\hline USDA-ARS, Kerr County & KER & Kerrville, TX & 2 May 1993 \\
\hline Buffalo Point, MB & BPT1 & Canada & 19 July 1993 \\
\hline Buffalo Point, MB & BPT2 & Canada & 11 Aug. 1994 \\
\hline
\end{tabular}

' Laboratory colony established in 1952.

er augmented; S. Kunz, personal communication). Flies were preserved at $-80^{\circ} \mathrm{C}$, except for the 1994 Buffalo Point, MB, sample (BPT2), which was preserved in $70 \%$ ethanol. Voucher specimens were deposited in the University of Nebraska State Museum, Lincoln, NE.
Allozyme Analysis. Fifty to 75 flies from each collection (except BPT2) and an equal number of each sex were analyzed. Sex of flies was determined and their heads removed for future molecular analyses. Decapitated bodies were homogenized in a 1.5-ml eppendorf tube with $80 \mu \mathrm{l}$ of

Table 2. Thirty-four stable fly enzyme systems screened and 10 systems used in this study

\begin{tabular}{|c|c|c|c|c|}
\hline Abbreviation' & Enzyme & E.C. no!' & Loci no. & Buffer \\
\hline$\overline{\mathrm{AAT}}$ & Aspartate aminotransferase & 2.6.1.1 & 2 & TBE \\
\hline ACPH' & Acid phosphatase & 3.1 .3 .2 & 1 & TBE \\
\hline ACOHd & Aconitase hydratase & 4.2.1.3 & 1 & TC \\
\hline $\mathrm{ADH}$ & Alcohol dehydrogenase & 1.1.1.1 & - & $\mathrm{TC}$ \\
\hline ALPH & Alkaline phosphatase & 3.1 .3 .1 & - & TBE \\
\hline $\mathrm{AO}^{\circ}$ & Aldehyde oxidase & 1.2.3.1 & 1 & TBE \\
\hline CAP & Cytosol aminopeptidase & 3.4.11.1 & 2 & TBE \\
\hline CAT & Catalase & 1.11.1.6 & - & TBE \\
\hline $\mathrm{DDH}$ & Dihydrolipoamide dehydrogenase & 1.8.1.4 & 2 & $\mathrm{TC}$ \\
\hline EST' & Esterase & 3.1.1.1 & 6 & TC \\
\hline FBA & Fructose-biphosphate aldolase & 4.1.2.13 & 1 & TC \\
\hline FBP & Fructose-biphosphate & 3.1.3.11 & - & $\mathrm{TC}$ \\
\hline $\mathrm{FDH}$ & Formaldehyde dehydrogenase & 1.2 .1 .1 & 2 & TBE \\
\hline FUMH & Fumarate hydratase & 4.2.1.2 & 1 & TC \\
\hline GCD & Glycerol dehydrogenase & 1.1.1.72 & 1 & TC \\
\hline GO & Glucose oxidase & 1.1.3.4 & - & TBE \\
\hline GDH & Glucose dehydrogenase & 1.1.1.118 & - & $\mathrm{TC}$ \\
\hline G3PDH & Glycerol-3-phosphate dehydrogenase & 1.1.1.8 & 1 & $\mathrm{TC}$ \\
\hline G6PDH & Glucose-6-phosphate dehydrogenase & 1.1.1.49 & 1 & TBE \\
\hline GAPDH & Glyceraldehyde-3-phosphate dehydrogenase & 1.2.1.12 & 1 & $\mathrm{TC}$ \\
\hline HADH & 3-Hydroxy butyrate dehydrogenase & 1.1.1.30 & 1 & TBE \\
\hline $\mathrm{HK}$ & Hexokinase & 2.7 .1 .1 & 3 & TBE \\
\hline IDH & Isocitrate dehydrogenase & 1.1.1.42 & 1 & $\mathrm{TC}$ \\
\hline $\mathrm{LDH}$ & L-Lactate dehydrogenase & 1.1.1.27 & 1 & TBE \\
\hline $\mathrm{MDH}$ & Malate dehydrogenase & 1.1.1.37 & 1 & $\mathrm{TC}$ \\
\hline MDHP & Malate dehydrogenase (NADP+) & 1.1.1.40 & 1 & TBE \\
\hline MPI & Mannose-6-phosphate isomerase & 5.3.1.8 & 1 & TBE \\
\hline PGDH & Phosphogluconate dehydrogenase & 1.1.1.44 & 1 & $\mathrm{TC}$ \\
\hline PGI & Phosphoglucoisomerase & 5.3.1.9 & 1 & TBE \\
\hline PGM & Phosphoglucomutase & 5.4.2.2 & 1 & TBE \\
\hline SOD & Superoxide dismutase & 1.15.1.1 & 1 & TBE \\
\hline TPI & Triose-phosphate isomerase & 5.3.1.1 & 1 & TBE \\
\hline THE & Trehalase & 3.2.1.28 & 4 & TBE \\
\hline $\mathrm{XDH}$ & Xanthine dehydrogenase & 1.1.1.204 & 1 & TBE \\
\hline
\end{tabular}

_, No interpretable staining.

' Abbreviations from Murphy et al. (1990).

b International Union of Biochemistry (1984).

Used by Krafsur (1993).

${ }^{d}$ Used for study.

e Used by Jones et al. (1991). 
grinding buffer (10\% sucrose, $0.01 \%$ bromophenol blue, $0.1 \%$ Triton X-100 dissolved in Tris-citrate electrode buffer diluted 1:5). One or $2 \boldsymbol{\mu l}$ of homogenate was used for each enzyme system.

Polyacrylamide gels (6\%) were made following methods of Black and Krafsur (1985). Electrophoresis equipment and methods were similar to Taylor and Peterson (1994). Stain recipes were derived from Munstermann (1979, 1980). After staining, gels were scored, fixed and preserved on cellulose membrane sheets using a Model 583 gel drier (Bio-Rad, Hercules, CA). Alleles for each locus were identified by their migration distances from the origin ( $\mathrm{Rf}$ ) relative to the most frequent allele (designated as 100) in the Kerrville laboratory colony. Thirty-four enzyme systems were screened (Table 2). Ten enzyme systems were selected for the study based on reliability of staining and interpretation of banding patterns in terms of Mendelian characters.

Polymerase Chain Reaction-Restriction Fragment Length Polymorphism. DNA extraction, polymerase chain reaction-restriction fragment length polymorphism (PCR-RFLP) and restriction digest techniques were similar to Taylor et al. (1996). Four amplicons were analyzed representing ' $42 \%$ of the mitochondrial genome (Table 3). Amplicon I was $2.4 \mathrm{~kb}$ long and included portions of cytochrome oxidase (CO) I and 1I genes; amplicon 1I was $2.3 \mathrm{~kb}$ long and included portions of CO I1 and CO 1 I1 genes; amplicon 1I1 was $1.5 \mathrm{~kb}$ long and included portions of CO I1I and nicotinamide adenine dehydrogenase (NADH) 5 genes; and amplicon IV was $257 \mathrm{bp}$ long and included a portion of the NADH 4 gene. Primers rDNA1 and rDNA2.144 were used to amplify a portion of the nuclear rDNA gene family (Table 3). The 2-kb amplicon included a portion of the $18 \mathrm{~S}$ and $28 \mathrm{~S}$ rDNA genes, internally transcribed spacers (ITS) 1 and 2, and the entire 5.8S rDNA gene. Fourteen to 16 restriction enzymes (New England Biolabs, Beverly, MA) were screened on all mtDNA amplicons and 14 restriction enzymes were used for the rDNA amplicon (Table 4).

Five flies each from BPT1, BPT2, PA3, KER, and ELG (Table 1) were used for the mtDNA RFLP analysis. Two individuals from BPT2, PA3, and KER were used for the nuclear rDNA RFLP analysis.

Statistical Methods. Allozyme loci were considered polymorphic when the most common allele had a frequency $<0.95$ in each population. BIOSYS-1 (Swofford and Selander 1981) was used to calculate expected heterozygosity, $\mathrm{H}_{e}$, Wright's inbreeding coefficient, Wright's $F$ statistic, and Nei's (1978) unbiased minimum distance, D. Wright's (1978) hierarchical analysis of breeding structure for a subdivided population ( $F$ statistics) was used to identify sources of spatial differentiation in gene frequencies. Significant deviation from 0 of Wright's FsT and FIT statistics was determined by

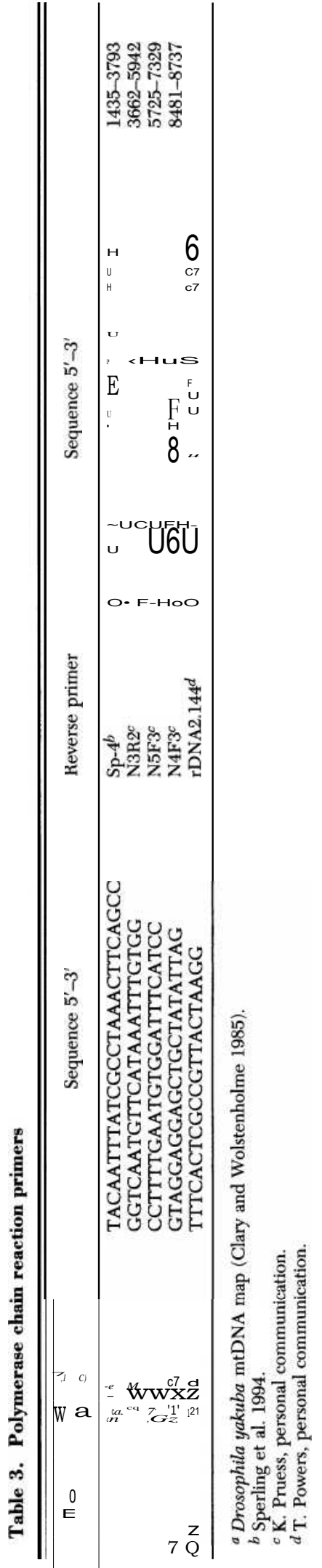


Table 4. Nei's genetic distance among 13 populations of stable fly

\begin{tabular}{|c|c|c|c|c|c|c|c|c|c|c|c|c|}
\hline Population SEW & HIC & VAL & PA1 & PA2 & PA3 & PA4 & GRI & STP & DAN & ELG & KER & BPTI \\
\hline$\overline{\mathrm{SEW}}$ & 0.000 & 0.000 & 0.001 & 0.004 & 0.001 & 0.001 & 0.001 & 0.000 & 0.002 & 0.001 & 0.054 & 0.000 \\
\hline HIC & & 0.000 & 0.000 & 0.002 & 0.000 & 0.000 & 0.000 & 0.000 & 0.001 & 0.000 & 0.055 & 0.000 \\
\hline VAL & & & 0.000 & 0.003 & 0.000 & 0.000 & 0.000 & 0.000 & 0.000 & 0.000 & 0.046 & 0.000 \\
\hline PA1 & & & & 0.001 & 0.000 & 0.000 & 0.000 & 0.000 & 0.001 & 0.000 & 0.051 & 0.000 \\
\hline PA2 & & & & - & 0.004 & 0.000 & 0.000 & 0.002 & 0.005 & 0.001 & 0.043 & 0.000 \\
\hline PA3 & & & & & - & 0.001 & 0.001 & 0.000 & 0.000 & 0.000 & 0.062 & 0.000 \\
\hline PA4 & & & & & & & 0.000 & 0.000 & 0.002 & 0.000 & 0.053 & 0.000 \\
\hline GRI & & & & & & & & 0.000 & 0.001 & 0.000 & 0.043 & 0.000 \\
\hline STP & & & & & & & & & 0.000 & 0.000 & 0.057 & 0.000 \\
\hline DAN & & & & & & & & & & 0.001 & 0.060 & 0.001 \\
\hline ELG & & & & & & & & & & & 0.044 & 0.000 \\
\hline KER & & & & & & & & & & & & 0.067 \\
\hline BPT1 & & & & & & & & & & & & \\
\hline
\end{tabular}

calculating chi-square statistics with the following formulas $\mathrm{X}^{2 F_{\mathrm{sT}}}=2 \mathrm{~N}\left(F \mathrm{~s}_{\mathrm{T}}\right)(k-1)$ with $(k-1)(s$ - I) df and $\mathrm{X}^{2 F_{\mathrm{IT}}}=(F I T)^{2} \mathrm{~N}(\mathrm{k}-\mathrm{I})$ with $\mathrm{k}(\mathrm{k}-\mathrm{I})$ $\mathrm{df}$ for $\mathrm{k}$ alleles and $\mathrm{s}$ populations.

Three levels of spatial variability were examined: among feedlots within regions ( $<40 \mathrm{~km}$ apart), between 2 regions separated by $130 \mathrm{~km}$, and among spatially distant populations ( $>200 \mathrm{~km}$ apart). Sampling sites were grouped into the following 5 regions: (1) Lincoln, (2) Grand Island, (3) Elgin, NE, (4) Texas, and (5) Canada, based on their relative geographic distance from each other. All of the regions together formed the total population. Wright's $F$ statistics were used to detect variation within and between Lincoln and Grand Island regions, samples within Nebraska relative to the Canadian sample, field samples relative to the laboratory sample, and variation among the temporal samples.

Tests for conformance to Hardy-Weinberg equilibrium (Swofford and Selander 1981) were conducted on 12 sample sites using a chi-square test with the Yates adjustment for small expected frequencies. Contingency chi-square tests, with Yates adjustment, were used on 4 polymorphic loci to test for homogeneity of allele frequencies.

\section{Results}

Enzyme Systems. Of the 34 enzyme systems evaluated, 10 (ACOH, FDH, GCD, G3PDH, GAPDH, HADH, IDH, LDH, MDH, and PGDH) were used in this study (Table 2). These 10 enzyme systems provided 11 interpretable loci. Of the enzyme systems not used, 6 (ADH, ALPH, CAT, FBP, GO, and GDH) failed to stain, 8 (ACPH, FBA, DDH, FUMH, G6PDH, SOD, TRE, and $\mathrm{XDH}$ ) were either too weak or inconsistent to score reliably, 3 (AAT, MPI, and PGI) could not be used because of blurry staining, and 7 (AO, EST, HK, CAP, MDHP, PGM, and TPI) had uninterpretable banding patterns.

Although HK exhibited a high degree of polymorphism for 2 apparent loci, it was not included in the analysis because of difficulty in interpreting the genetic basis of the phenotypes. Octanol dehydrogenase (ODH), stained the same enzyme as formaldehyde dehydrogenase $(\mathrm{FDH})$. This phenomena was observed in blowflies (Taylor and Peterson 1994) and mammals (Hur and Edenberg 1992).

Allozyme Phenotypes. All systems used for this study had 1 locus, except for FDH which had 2, FDH-1 and FDH-2. Acoh and Gcd heterozygotes exhibited a 2-banded pattern characteristic of a monomeric structure. Fdh-1, Hadh, and Pgdh heterozygotes exhibited a 3-banded pattern characteristic of a dimeric structure. No heterozygotes for G3pdh, Gapdh, and Mdh were observed preventing characterization the structure of these isozymes.

Population Structure. Variation was detected in 7 of the 11 loci studied. Four loci (36\%) were polymorphic (Table 5). An average of I.5 alleles per locus was observed. Three loci (Gapdh, G3pdh, and $M d h$ ) were monomorphic, and 2 (Gcd and $P g d h$ ) were polymorphic for all populations sampled with the exception of Pgdh in the PA3 collection. Two loci had rare alleles, $F<0.01$ (Jones et al. 1991). One Idh (070/100) heterozygote was detected from Elgin, NE (ELG) and a Fdh-2 (083/100) heterozygote was observed at St. Paul, NE (STP). Observed and expected levels of heterozygosity for field populations were 0.09 and 0.07 , respectively (Table 6). Genotypic frequencies for 5 loci deviated significantly $(\mathrm{P}<0.05)$ from Hardy-Weinberg equilibrium (PA1 Gcd, PA4 Gcd, GRI Gcd, DAN Fdh-1, and KER Gcd). Contingency chi-square analysis revealed no differentiation $(\mathrm{P}<0.05)$ in allele frequencies among samples (Table 7).

Wright's $F$ statistics (Table 7) revealed no departures from random mating. Chi-square test revealed no deviation $(\mathrm{P}<0.05)$ from 0 for $F S_{\mathrm{T}}$ and $F_{\text {IT }}$ values (Table 8 ). Variation within populations $\left(F_{\text {IS }}\right)$ from Nebraska and Canada was greater than variation between these populations $\left(F_{S_{\mathrm{T}}}\right)$ (Table 8). Genetic differentiation was greatest between the field populations and the Kerrville laboratory population. 
Table 5. Gene frequencies for variable loci in 13 populations of stable fly

\begin{tabular}{|c|c|c|c|c|c|c|c|c|c|c|c|c|c|c|c|}
\hline \multirow{2}{*}{ Locus } & \multirow{2}{*}{ Allele $^{\circ}$} & & \multicolumn{13}{|c|}{ Population } \\
\hline & & & SEW & $\mathrm{HIC}$ & VAL & PA1 & PA2 & PA3 & PA4 & GRI & STP & DAN & ELG & KER & BPT1 \\
\hline \multirow[t]{6}{*}{ Acoh } & $\mathrm{N}$ & Mean & 75 & 75 & 50 & 75 & 49 & 75 & 46 & 49 & 49 & 50 & 50 & 74 & 49 \\
\hline & 095 & 0.005 & 0.000 & 0.000 & 0.000 & 0.013 & 0.000 & 0.013 & 0.000 & 0.000 & 0.000 & 0.000 & 0.040 & 0.000 & 0.000 \\
\hline & 100 & 0.972 & 1.000 & 0.967 & 0.980 & 0.947 & 1.000 & 0.987 & 1.000 & 0.980 & 0.969 & 1.000 & 0.920 & 0.912 & 0.969 \\
\hline & 103 & 0.023 & 0.000 & 0.033 & 0.020 & 0.040 & 0.000 & 0.000 & 0.000 & 0.020 & 0.031 & 0.000 & 0.040 & 0.088 & 0.031 \\
\hline & $\mathrm{He}$ & 0.054 & 0.000 & 0.060 & 0.040 & 0.100 & 0.000 & 0.030 & 0.000 & 0.040 & 0.060 & 0.000 & 0.150 & 0.160 & 0.060 \\
\hline & $\mathrm{X}^{2}$ & & 0.000 & $13.695^{\circ}$ & 0.010 & 0.207 & 0.000 & 0.007 & 0.000 & 0.011 & 0.032 & 0.000 & 0.328 & 0.493 & 0.032 \\
\hline \multirow[t]{6}{*}{ Fdh-1 } & $\mathrm{N}$ & & 72 & 75 & 50 & 75 & 50 & 75 & 40 & 48 & 49 & 50 & 50 & 75 & 49 \\
\hline & 094 & 0.001 & 0.000 & 0.000 & 0.010 & 0.000 & 0.000 & 0.000 & 0.000 & 0.000 & 0.000 & 0.000 & 0.000 & 0.000 & 0.010 \\
\hline & 100 & 0.960 & 0.931 & 0.947 & 0.940 & 0.967 & 1.000 & 0.967 & 0.950 & 0.969 & 0.959 & 0.940 & 0.950 & 1.000 & 0.959 \\
\hline & 114 & 0.039 & 0.069 & 0.053 & 0.050 & 0.033 & 0.000 & 0.033 & 0.050 & 0.031 & 0.041 & 0.060 & 0.050 & 0.000 & 0.031 \\
\hline & $\mathrm{He}$ & 0.076 & 0.130 & 0.100 & 0.110 & 0.060 & 0.000 & 0.060 & 0.100 & 0.060 & 0.080 & 0.110 & 0.100 & 0.000 & 0.080 \\
\hline & $x^{2}$ & & 0.359 & 0.207 & 0.168 & 0.424 & 0.000 & 0.710 & 0.082 & 0.033 & 0.066 & $25.628^{\circ}$ & 0.110 & 0.000 & 0.066 \\
\hline \multirow[t]{5}{*}{ Gcd } & $\mathrm{N}$ & & 69 & 45 & 48 & 71 & 44 & 34 & 50 & 45 & 49 & 50 & 48 & 74 & 48 \\
\hline & 100 & 0.494 & 0.580 & 0.556 & 0.577 & 0.521 & 0.398 & 0.603 & 0.460 & 0.489 & 0.561 & 0.620 & 0.521 & 0.169 & 0.500 \\
\hline & 121 & 0.496 & 0.420 & 0.444 & 0.423 & 0.479 & 0.602 & 0.397 & 0.540 & 0.511 & 0.439 & 0.380 & 0.479 & 0.831 & 0.500 \\
\hline & $\mathrm{He}$ & 0.480 & 0.490 & 0.500 & 0.500 & 0.500 & 0.480 & 0.490 & 0.500 & 0.510 & 0.500 & 0.480 & 0.500 & 0.280 & 0.510 \\
\hline & $\mathrm{Y}^{2}$ & & 0.001 & 1.135 & 0.181 & $6.013^{\circ}$ & 0.279 & 0.029 & $35.440^{\circ}$ & $6.800^{\circ}$ & 1.796 & 0.438 & 2.803 & $6.137^{\circ}$ & 2.228 \\
\hline \multirow[t]{6}{*}{ Had-1 } & $\mathrm{N}$ & & 75 & 75 & 50 & 75 & 50 & 75 & 50 & 49 & 49 & 50 & 50 & 74 & 49 \\
\hline & A & 0.001 & 0.000 & 0.007 & 0.000 & 0.000 & 0.000 & 0.000 & 0.000 & 0.000 & 0.000 & 0.000 & 0.000 & 0.000 & 0.000 \\
\hline & B & 0.991 & 0.973 & 0.987 & 1.000 & 0.993 & 0.970 & 1.000 & 1.000 & 1.000 & 1.000 & 1.000 & 0.990 & 1.000 & 0.980 \\
\hline & $\mathrm{C}$ & 0.008 & 0.027 & 0.007 & 0.000 & 0.007 & 0.030 & 0.000 & 0.000 & 0.000 & 0.000 & 0.000 & 0.010 & 0.000 & 0.020 \\
\hline & $\mathrm{He}$ & 0.016 & 0.052 & 0.030 & 0.000 & 0.010 & 0.060 & 0.000 & 0.000 & 0.000 & 0.000 & 0.000 & 0.020 & 0.000 & 0.040 \\
\hline & $x^{2}$ & & 0.042 & 0.007 & 0.000 & 0.000 & 0.032 & 0.000 & 0.000 & 0.000 & 0.000 & 0.000 & 0.000 & 0.000 & 0.011 \\
\hline \multirow[t]{6}{*}{ Pgdh } & $\mathrm{N}$ & & 69 & 74 & 50 & 75 & 50 & 75 & 40 & 48 & 49 & 49 & 50 & 74 & 49 \\
\hline & 089 & 0.049 & 0.036 & 0.034 & 0.020 & 0.007 & 0.010 & 0.007 & 0.000 & 0.021 & 0.020 & 0.031 & 0.030 & 0.392 & 0.031 \\
\hline & 100 & 0.893 & 0.841 & 0.899 & 0.920 & 0.927 & 0.939 & 0.959 & 0.920 & 0.948 & 0.918 & 0.918 & 0.910 & 0.608 & 0.908 \\
\hline & 118 & 0.057 & 0.123 & 0.068 & 0.060 & 0.067 & 0.051 & 0.034 & 0.080 & 0.031 & 0.061 & 0.051 & 0.060 & 0.000 & 0.061 \\
\hline & $\mathrm{He}$ & 0.175 & 0.270 & 0.180 & 0.150 & 0.140 & 0.120 & 0.080 & 0.150 & 0.100 & 0.150 & 0.110 & 0.170 & 0.480 & 0.170 \\
\hline & $x^{2}$ & & 0.082 & 0.873 & 0.328 & 0.424 & 0.172 & 0.109 & 0.328 & 0.115 & 0.336 & 0.322 & 0.431 & 0.014 & 0.441 \\
\hline
\end{tabular}

$\mathrm{N}$, number of individuals in each sample; He, expected heterozygosity; $\mathrm{X}^{2}$, deviation from the Hardy-Weinberg equilibrium.

Populations not in equilibrium.

Nei's genetic distances (Nei 1978), D, among field collections averaged $0.001(\mathrm{SEM}=0.001)$ and ranged from 0.000 to 0.005 (Table 4). Genetic distances among the 4 temporal collections from the Panama, NE, feedlot were $<0.005$. Genetic distance between field collections and KER colony ranged from 0.044 to 0.067 . Number of migrants $(\mathrm{Nm})$ was calculated using the formula $([\mathrm{Nm}=(1$ - FST) / 4FST]) (Wright 1951). The number of

Table 6. Genetic variability in sampled stable fly populations

\begin{tabular}{lccc}
\hline $\begin{array}{c}\text { Popu- } \\
\text { lation }\end{array}$ & $\begin{array}{c}\text { \% loci } \\
\text { polymor- } \\
\text { phis }^{\circ}\end{array}$ & $\begin{array}{c}\text { Observed } \\
\text { heterozygosity } \\
\pm \mathrm{SE}\end{array}$ & $\begin{array}{c}\text { Expected } \\
\text { heterozygosity } \\
\pm \mathrm{SE}\end{array}$ \\
\hline SEW & 27.3 & $0.086 \mathrm{~T} 0.048$ & $0.087 \pm 0.048$ \\
HIC & 27.3 & $0.087 \pm 0.053$ & $0.080 \pm 0.046$ \\
VAL & 27.3 & $0.078 \pm 0.049$ & $0.073 \pm 0.045$ \\
PA1 & 27.3 & $0.089 \pm 0.058$ & $0.075 \pm 0.045$ \\
PA2 & 18.2 & $0.064 \pm 0.047$ & $0.060 \pm 0.044$ \\
PA3 & 9.1 & $0.061 \pm 0.045$ & $0.060 \pm 0.043$ \\
PA4 & 27.3 & $0.107 \pm 0.068$ & $0.068 \pm 0.046$ \\
GRI & 18.2 & $0.047 \pm 0.028$ & $0.064 \pm 0.045$ \\
STP & 18.2 & $0.083 \pm 0.053$ & $0.074 \pm 0.045$ \\
DAN & 18.2 & $0.058 \pm 0.047$ & $0.061 \pm 0.043$ \\
ELC & 36.4 & $0.100 \pm 0.056$ & $0.087 \pm 0.046$ \\
KER & 33.3 & $0.086 \pm 0.043$ & $0.102 \pm 0.048$ \\
BPT1 & 18.2 & $0.094 \pm 0.060$ & $0.078 \pm 0.046$ \\
Mean ${ }^{{ }^{\prime}}$ & 22.8 & $0.086 \pm 0.019$ & $0.070 \pm 0.010$ \\
\hline
\end{tabular}

${ }^{\circ}$ Frequency of most common allele 0.95 .

b Excludes KER population. migrants needed to maintain the observed FST $(F S T=0.067)$ value between the Canadian and Kerrville populations was 3.48 individuals per generation and $\mathrm{Nm}$ between the Lincoln and Grand Island localities was 11.8 individuals per generation $(F S T=0.016)$.

Polymerase Chain Reaction-Restriction Fragment Length Polymorphism. DNA was extracted and amplified from frozen and alcohol preserved adults. Thirteen restriction sites were observed in amplicon I, 15 in amplicon II, 5 in amplicon III, and 9 in amplicon IV (Table 9). The 46 restriction sites represent $=\mathrm{I} \%$ of the mitochondria) genome. None of the restriction sites were polymorphic. Restriction analysis revealed 12 restriction sites within the 2-kb nuclear rDNA amplicon (Table 9) and fragment patterns were identical for all sampled individuals.

Table 7. Summary of Wright (1978) F statistics for all stable fly collections

\begin{tabular}{lrcr}
\hline Locus & \multicolumn{1}{c}{ Fis $_{\text {is }}$} & F $_{\text {ST }}$ & \multicolumn{1}{c}{ F $_{\text {IT }}$} \\
\hline Acoh & 0.023 & 0.027 & 0.050 \\
Gcd & -0.154 & 0.051 & -0.095 \\
Had & -0.022 & 0.014 & -0.008 \\
Pgdh & -0.043 & 0.104 & 0.066 \\
Fdh-1 & 0.029 & 0.011 & 0.039 \\
Mean & -0.033 & 0.041 & 0.010 \\
\hline
\end{tabular}


Table 8. Nested analysis of variance of gene frequencies of stable fly populations

\begin{tabular}{|c|c|c|c|}
\hline Contrast & Comparison & Variance component & ${ }^{\mathrm{F}} x y$ \\
\hline \multirow[t]{3}{*}{ Lincoln vs Grand Island region } & Feedlot (region) & 0.006 & 0.008 \\
\hline & Region (total) & -0.002 & -0.003 \\
\hline & Feedlot (total) & 0.004 & 0.006 \\
\hline \multirow[t]{3}{*}{ Nebraska region vs Canada region } & Feedlot (region) & 0.007 & 0.005 \\
\hline & Region (total) & 0.001 & 0.001 \\
\hline & Feedlot (total) & 0.008 & 0.006 \\
\hline \multirow{3}{*}{$\begin{array}{l}\text { Field populations (NE and MB) } \\
\text { vs laboratory (TX) population }\end{array}$} & Population (source) & 0.004 & 0.005 \\
\hline & Source (total) & 0.035 & 0.041 \\
\hline & Population (total) & 0.039 & 0.046 \\
\hline
\end{tabular}

\section{Discussion}

Geographical and temporal differentiation is low in the stable fly. This is characteristic of species that are a single, large panmictic population (Eanes and Koehn 1978). Genetic homogeneity among populations may be promoted by the dispersal capacity of the stable fly. Such dispersal will facilitate the spread of advantageous genes, such as insecticide resistance.

Wright's (1978) FST was greatest (0.041) comparing field samples to the Kerrville colony. This value was $<0.05$, indicating low levels of genetic differentiation of stable fly populations (Wright 1978). FST values among field populations essentially indicated no genetic differentiation. Low Nei's genetic distance values support the lack of differentiation between populations. The values of $\mathrm{Nm}$ indicated high levels of gene flow between populations (Schnabel and Hamrick 1990).
The percentage of polymorphic allozyme loci and mean heterozygosity in this study was intermediate to previous stable fly allozyme studies (Jones et al. 1991, Krafsur 1993). Mean heterozygosity $(\mathrm{He}=0.096)$ and expected heterozygosity for Acoh, Hadh, Fdh-I (Odh-2), and Pgdh were similar between this study and Krafsur (1993). Although the lack of differentiation among populations in this study agreed with Jones et al. (1991), we observed higher levels of variability $(36 \%$ polymorphic loci, $\mathrm{He}=0.09$ ) within populations. Five loci (Table 5) were the same as Jones et al. (1991), but variation for Pgdh, Acoh, and Hadh was greater in our study. We did not observe rare homozygotes as did Jones et al. (7991), although we did detect rare heterozygotes for $F d h-2$ and $I d h$. The average genetic distances (Nei 1978) between stable fly populations of 0.001 found in our study was comparable to that of Jones et al. (1991).

Table 9. Estimated restriction fragment lengths for stable fly

\begin{tabular}{|c|c|c|c|c|c|}
\hline \multirow{2}{*}{$\begin{array}{l}\text { Restric- } \\
\text { tion } \\
\text { enzyme }\end{array}$} & \multicolumn{5}{|c|}{ Amplicon } \\
\hline & $\mathrm{I}, 2.4 \mathrm{~kb}$ & $\mathrm{H}, 2.3 \mathrm{~kb}$ & $\mathrm{HI}, 1.5 \mathrm{~kb}$ & IV, 257 bp & ITS, $2.0 \mathrm{~kb}$ \\
\hline Abs I & $\mathrm{NU}^{\prime}$ & $\mathrm{NU}$ & $\mathrm{NU}$ & 133,107 & $\mathrm{NU}$ \\
\hline Apo I & $\mathrm{NU}$ & NU & $\mathrm{NU}$ & $\mathrm{NU}$ & $566,446,431,378$ \\
\hline Ase I & $1460,295,225,184,176,137$ & NU & $\mathrm{NU}$ & $124,88,26$ & $493,461,354,342,272$ \\
\hline Ava I & 1507,1058 & NU & $\mathrm{NU}$ & 257 & 2005 \\
\hline Ban II & $1774,744,300$ & 1650,650 & 1604 & 257 & 2005 \\
\hline$B f a \mathrm{I}$ & 2364 & $1100,1000,200$ & 1604 & $\mathrm{NU}$ & $\mathrm{NU}$ \\
\hline$B s r 1$ & 2364 & 1415,866 & 1253,350 & $\mathrm{NU}$ & 1435,516 \\
\hline Dde I & 2364 & 2281 & $953,386,250$ & 257 & NU \\
\hline Dpn $\mathrm{H}$ & 2364 & 2281 & $754,619,231$ & 257 & $\mathrm{NU}$ \\
\hline Dra I & $1357,825,750$ & $1150,550,450,150$ & 1604 & 257 & $\mathrm{NU}$ \\
\hline ECOR I & 2364 & 1753,527 & 1604 & 257 & 2005 \\
\hline EcoR V & 1450,1350 & 2150,150 & 1604 & $\mathrm{NU}$ & 1107,793 \\
\hline Hae HI & 2364 & 2281 & 1604 & $\mathrm{NU}$ & $\mathrm{NU}$ \\
\hline Hine $\mathrm{H}$ & 1937,851 & 1450,850 & 1604 & $\mathrm{NU}$ & 2005 \\
\hline Hind HI & 2364 & 2281 & 1604 & NU & 1488,517 \\
\hline Hpa I & $\mathrm{NU}$ & $\mathrm{NU}$ & $\mathrm{NU}$ & $\mathrm{NU}$ & 2005 \\
\hline $\operatorname{Hinf} \mathrm{I}$ & $1029,827,412,84$ & 2281 & 1604 & 257 & $\mathrm{NU}$ \\
\hline Mse I & NU & $\mathrm{NU}$ & $\mathrm{NU}$ & $81,81,30,22,14,11$ & $\mathrm{NU}$ \\
\hline$M s p I$ & 2364 & 2281 & 1604 & $\mathrm{NU}$ & 2005 \\
\hline Pvu 11 & 2364 & $1150,825,325$ & 1604 & $\mathrm{NU}$ & 2005 \\
\hline Rsa 1 & $1087,829,750$ & 2025,275 & 1604 & NU & $\mathrm{NU}$ \\
\hline Sau96I & $\mathrm{NU}$ & $\mathrm{NU}$ & $\mathrm{NU}$ & $\mathrm{NU}$ & 2005 \\
\hline ScrF 1 & 2364 & 1416,864 & 1604 & 257 & $\mathrm{NU}$ \\
\hline Ssp I & $\mathrm{NU}$ & $\mathrm{NU}$ & $\mathrm{NU}$ & 128,111 & $\mathrm{NU}$ \\
\hline aTaq & $\mathrm{NU}$ & $\mathrm{NU}$ & $\mathrm{NU}$ & $\mathrm{NU}$ & $1206,448,348$ \\
\hline $\mathrm{Xba} 1$ & NU & 1200,1100 & $\mathrm{NU}$ & NU & $\mathrm{NU}$ \\
\hline No. sites & 17 & 15 & 5 & 9 & 12 \\
\hline
\end{tabular}

" NU, enzyme not used. 
Restriction Fragment Length Polymorphism analysis of the nuclear and mitochondrial genomes revealed no variation within or among populations, supporting the allozyme evidence for minimal genetic differentiation. PCR-RFLP analyses on the same mtDNA amplicons used in this study have been conducted on 2 species of blow flies, primary screwworm, Cochliomyia hominovorax (Coquerel), and secondary screwworm, C. rnacelleria $(F$.), from North, Central, and South America (unpublished data). High levels of intraspecific variation were detected in primary screwworm, but like stable fly, the secondary screwworm exhibited a single haplotype. Levels of allozyme variation were similar for these 2 species (Taylor and Peterson 1994). The pattern of variation may be the result of the historical dispersal patterns (Avise 1987). Differences in allozyme and molecular variation illustrate the importance of using both as genetic markers (Milton 1994).

Nuclear rDNA provides an alternative to $\mathrm{mt}-$ DNA for detecting genetic variation within and among populations, because of differences in the modes of inheritance (Weller et al. 1994). In this study, no detectable variation was observed in the rDNA gene family. This lack of variation in the nuclear genome is concordant with the lack of variation detected in the mitochondrial genome.

Several factors may contribute to low levels of genetic variability in stable fly populations. The stable fly probably was introduced to North American during the mid 18th century (Hall and Smith 1986). The colonizers likely consisted of individuals of European origin shipped with cattle across the Atlantic. Population bottlenecks are important during the establishment of new populations. Excessive contributions to the gene pool by a few individuals during this period (genetic drift) reduces the genetic variability in subsequent generations (founders effect). For example in the face fly, an estimated $50 \%$ of the alleles available in Europe were lost with its introduction to North America (Bryant et al. 1981). Finally, the period since the introduction of stable fly to North America is insufficient for the development of new variation. For the average animal mtDNA genome, 1 site substitution is expected every 3,000 years (Avise 1994).

\section{Acknowledgments}

We thank Lloyd R. Criffield for assistance in collecting flies and Kenneth Pnuess for assistance with primer selection. John Foster, James Petersen, and Steve Skoda provided helpful suggestions and critical reviews of the manuscript. This work was done in cooperation with the Institute of Agriculture and Natural Resources, University of Nebraska, Lincoln, and is published as Journal Series, Nebraska Agricultural Research Division paper 10721.

\section{References Cited}

Avise, J. C. 1994. Molecular markers, natural history and evolution. Chapman \& Hall, New York, NY.

Avise, J. C., J. Arnold, R. M. Ball, E. Bermingham, T. Lamb, J. E. Neigel, C. Reeb, and N. C. Saunders. 1987. Intraspecific phylogeography: the mitochondrial DNA bridge between population genetics and systematics. Annu. Rev. Ecol. Syst. 18: 489-522.

Berkebile, D. R., G. D. Thomas, and J. B. Campbell. 1994. Overwintering of the stable fly (Diptera: Muscidae) in southeastern Nebraska. J. Econ. Entomol. 87: 1555-1563.

Berry, I. L., K. W. Foerster, and J. B. Campbell. 1978. Overwintering behavior of stable flies in manure mounds. Environ. Entomol. 71: 67-72.

Black, W. C., IV, and E. S. Krafsur. 1985. Electrophoretic analysis of genetic variability in the house fly (Musca do7nestica L.). Biochem. Genet. 23: 193-203.

Bryant, E. H., H. Van Dijk, and W. Van Delden. 1981. Genetic variability of the face fly, Musca autumnalis De Geer, in relation to a population bottleneck. Evolution 35: 872-881.

Campbell, J. B., and J. F. Hermanussen. 1971. Efficacy of insecticides and methods of insecticidal application for control of stable flies in Nebraska. J. Econ. Entomol. 64: 1188-1190.

Christensen, C. M. 1982. External parasites of dairy cattle. J. Dairy Sci. 65: 2189-2193.

Eanes, W. F., and R. K. Koehn. 1978. An analysis of genetic structure in the monarch butterfly, Danaus plexippus L. Evolution 32: 784-797.

Estienne, M. J., F. W. Knapp, J. A. Boling, and J. G. Burg. 1991. Physiological and nutritional responses of beef steers exposed to stable files (Diptera: Muscidae). J. Econ. Entomol. 84: 1262-1265.

Hall, R. D., and J. P. Smith. 1986. Life history and economic importance of the stable fly, pp. 2-7. In Stable fly biology and control in cattle feedlots. Kans. Agric. Exp. Stn. Publ. 86-362-D.

Hoffman, R. A. 1968. The stable fly, Stomoxys calcitrans (L.): biology and behavior studies. Ph.D. dissertation, Oklahoma State University, Stillwater.

Hur, M. W., and H. J. Edenberg. 1992. Cloning and characterization of the ADII5 gene encoding human alcohol dehydrogenase-5, formaldehyde dehydrogenase. Gene 121: 305-311.

International Union of Biochemistry. 1984. Enzyme nomenclature. Academic, Orlando, FL.

Jones, C. J., R. S. Patterson, and D. E. Milne. 1987. Electrophoretic comparisons of isozymes from selected populations of Stomoxys calcitrans (Diptera: Muscidae). J. Med. Entomol. 24: 54-60.

Jones, C. J., J. A. Hogsette, R. S. Patterson, D. E. Milne, G. D. Propp, J. F. Milio, L. G. Rickard, and J. P. Ruff. 1991. Origin of stable flies (Diptera: Muscidae) on West Florida beaches: electrophoretic analysis of dispersal. J. Med. Entomol. 28: 787-795.

Krafsur, E. S. 1993. Allozyme variation in stable flies (Diptera: Muscidae). Biochem. Genet. 31: 231-240.

Milton, J. B. 1994. Molecular approaches to population biology. Annu. Rev. Ecol. Syst. 25: 45-69.

Munstermann, L. E. 1979. Isozymes of Aedes aegypti: phenotypes, linkage, and use in the genetic analysis of sympatric subspecies populations in East Africa. Ph.D. dissertation, University of Notre Dame, South Bend, IN.

1980. Distinguishing geographic strains of the Aedes atropalpu.s group (Diptera: Culicidae) by analysis of 
enzyme variation. Ann. Entomol. Soc. Am. 73: 699704.

Murphy, R. W., J. W. Sites, Jr., D. G. Butts, and C. H. Haufler. 1990. Proteins I: isozyme elctrophoresis, pp. 45-126. In D. M. Hillis and C. Moritz [eds.], Molecular systematics. Sinaur, Sunderland, MA.

Nei, M. 1978. Estimation of average heterozygosity and genetic distance from a small number of individuals. Genetics 89: 583-590.

Sebnabel, A., and J. L. Hamrick. 1990. Organization of genetic diversity within and among populations of Gleditsia triacanthos (Leguminosae). Am. J. Bot. 77: 1060-1069.

Skidmore, P. 1985. The biology of the muscidae of the world. Junk, Dordrecht.

Sperling, F.A.H., G. S. Anderson, and D. A. Hickey. 1994. A DNA-based approach to the identification of insect species used for postmortem interval estimation. J. Forensic Sci. 39: 418-427.

Swofford, D. L., and R. B. Selander. 1981. BIOSYS1: a FORTRAN program for the comprehensive analysis of electrophoretic data in population genetics and systematics. J. Hered. 72: 281-283.

Taylor, D. B., and R. D. Peterson II. 1994. Population genetics and gene variation in primary and secondary screwworm (Diptera: Calliphoridae). Annu. Entomol. Soc. 87: 626-633.
Taylor, D. B., A. L. Szalanski, and R. D. Peterson, It. 1996. Identification of screwworm species (Diptera: Calliphoridae) by polymerase chain reaction-restriction fragment length polymorphism. Med. Vet. Entomol. 10: 63-70.

Thomas G. D. 1993. The influence of beef cattle feedlots on the urban fly problem, pp. 1-6. In G. D. Thomas and S. R. Skoda [eds.], Rural flies in the urban environment? North Central Reg. Res. Publ. 335.

Thomas, G. D., I. L. Berry, D. R. Berkehile, and S. R. Skoda. 1989. Comparison of three sampling methods for estimating adult stable fly (Diptera: Muscidae) populations. Environ. Entomol. 18: 513-520.

Weiman, G. A., J. B. Campbell, J. A. Deshazer, and I. L. Berry. 1992. Effects of stable flies (Diptera: Muscidae) and heat stress on weight gain and feed efficiency of feeder cattle. J. Econ. Entomol. 85: 1835-1842.

Weller, S. J., D. P. Pashley, J. A. Martin, and J. L. Constable. 1994. Phylogeny of noctuoid moths and the utility of combining independent nuclear and mitochondrial genes. Syst. Biol. 43: 194-211.

Wright, S. 1951. The genetic structure of populations. Annu. Eugenet. 15: 323-354.

1978. Evolution and the genetics of populations, vol. 4. University of Chicago Press, Chicago.

Received for publication 5 July 1995; accepted 6 December 1995. 